\title{
Aromatic Schiff bases and 2,3-disubstituted-1,3-thiazolidin-4-one derivatives as antiinflammatory agents
}

\author{
Iana Vazzana ${ }^{a}$, Emanuela Terranova ${ }^{a}$, Francesca Mattioli ${ }^{b}$, and Fabio Sparatore ${ }^{\mathrm{a} *}$ \\ ${ }^{a}$ Dipartimento di Scienze Farmaceutiche, Università di Genova, Viale Benedetto XV, \\ 3 - 16132 Genova, Italy and \\ ${ }^{b}$ Dipartimento di Medicina Interna, Sezione di Farmacologia e Tossicologia Clinica, Università \\ di Genova, Viale Benedetto XV, 2 -16132 Genova, Italy \\ E-mail: sparator@unige.it
}

\section{Dedicated to Professor Vincenzo Tortorella, University of Bari, in the occasion of his "fuori ruolo" status \\ (received 14 Jan 04; accepted 12 May 04; published on the web 16 May 04)}

\begin{abstract}
Two small sets of aromatic Schiff bases and 2,3-diaryl-1,3-thiazolidin-4-one derivatives have been prepared and tested for antiinflammatory and antinociceptive activities. The thiazolidinone derivatives have been obtained from the azomethines through the addition of $\alpha$-mercaptoacetic acid. Both types of compounds displayed good level of activity against carrageenan induced edema in rat hind paw, while only moderate activity was observed in the writhing test in mice.
\end{abstract}

Keywords: Aromatic Schiff bases, 2,3-diaryl-1,3-thiazolidinon-4-one derivatives, antiinflammatory agents, anti-nociceptive agents

\section{Introduction}

For a long time we have described ${ }^{1}$ sets of Schiff bases (diaryl- and arylheteroaryl azomethines) endowed with strong and long lasting antiinflammatory activity against the rat hind paw edema induced by carrageenan. The $N$-(2/3/4-pyridinylmethylene)-3-trifluoromethylbenzenamines 1-3 were of particular interest. The observed activity was clearly exceeding that of the starting amines and aldehydes, as intensity and duration is concerned, and could be related either to a latentiation of the active amine with an improved site-specific delivery, or better to a direct interaction of the azomethine itself with some enzymatic or receptorial protein, maybe at the level of thiol groups. Indeed active azomethines had been previously obtained starting from surely inactive amines and aldehydes. ${ }^{2}$ 
Two azomethines ( $N$-vanillylidene-2,4-and 2,5-xylidine) have been described as generic cyclooxygenase inhibitors with $\mathrm{IC}_{50}$ in the range $24-29 \mu \mathrm{M}^{3}$ while several $N$-vanillylidene and $\mathrm{N}$-syringylidene 2-aminothiazole and 2-aminobenzothiazole were found endowed with inhibitory activities against carrageenan induced mice hind paw edema and of soybean lipoxygenase in vitro. ${ }^{4,5}$ The same compounds reduced, dose dependently, the nitric oxide and $\mathrm{PGE}_{2}$ production and also the glycosaminoglycans (GAGs) release from nasal pig cartilage cultures treated with interleukin $1 \beta .^{6}$ All these properties were mainly correlated with the presence of phenolic functions, which can display a generic antioxidant and radical scavenging activity, more than with the presence of the azomethine function. However it is worth noting that the vanillylidene derivatives of the amines previously considered by us, were devoid of any antiedema activity.<smiles>FC(F)(F)c1cccc(/N=C/c2ccccn2)c1</smiles><smiles>[Y]c1ccc(C=Nc2ccc([Y])cc2)cc1</smiles>

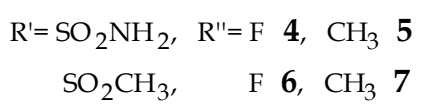
$4-7$<smiles>Cc1ccc(-c2cc(C(F)(F)F)nn2-c2ccc(C(N)=O)cc2)cc1</smiles>

CELECOXIB<smiles>O=C1CSC(c2cccnc2)N1c1cccc(C(F)(F)F)c1</smiles>

$8-10$<smiles>COc1ccc(C2=C(c3ccccc3)C(=O)OC2)cc1</smiles>

ROFECOXIB<smiles>Cc1onc(-c2ccccc2)c1-c1ccc(OS(N)(=O)=O)cc1</smiles>

VALDECOXIB<smiles>[R]c1ccc(N2C(=O)CSC2c2ccc(Br)cc2)cc1</smiles>

$11-14$

$$
\begin{aligned}
& \mathrm{R}^{\prime}=\mathrm{SO}_{2} \mathrm{NH}_{2}, \quad \mathrm{R}^{\prime \prime}=\mathrm{F} \quad \mathbf{1 1}, \mathrm{CH}_{3} 12 \\
& \mathrm{SO}_{2} \mathrm{CH}_{3} \text {, } \\
& \text { F 13, } \mathrm{CH}_{3} 14
\end{aligned}
$$

\section{Structure Block 1}


On the other hand the azomethine function is endowed with multiform reactivity and particularly is able to react with thiol groups, ${ }^{7}$ thus it could establish easily some kind of link with enzymatic or receptorial proteins.

The diarylazomethines are isosteric with stilbenes and, like these, can exist in interconvertible cis and trans forms. Suitably substituted cis-stilbene derivatives are characterized by potent inhibitory activity on $\mathrm{COX}-2$, quite similarly with what is observed for a variety of vicinal diarylheterocycles, among which important antiinflammatory drugs, like celecoxib, rofecoxib and valdecoxib, are found. ${ }^{8}$

In the last class of drugs the central five membered ring, may be of very different nature, either heterocyclic or carbocyclic, ${ }^{8-10}$ while the nature of substituents on the two benzene rings is believed to be responsible for COX-2 selectivity by insertion into the secondary pocket of the enzyme, with the p-sulfonamido and p-methylsulfonyl groups playing a key role.

Accordingly in order to improve the previously observed antiinflammatory activity we have now prepared some additional Schiff bases (4-7) bearing these peculiar substituents; moreover, through the reaction with $\alpha$-mercaptoacetic acid, the Schiff bases 1-7 were converted into 2,3diaryl-1,3-thiazolidin-4-one derivatives, imposing a cis conformation to the aromatic rings so that the molecules resemble very closely the mentioned antiinflammatory agents. On the other hand the binding capability of the azomethine function, which could play some peculiar role in the interaction with proteins, is lost in the new compounds.

\section{Results and Discussion}

The new Schiff bases 4, 5 and 7 were prepared similarly to those previously described ${ }^{1}$ by refluxing for 6 to 30 hours the solution in absolute ethanol of the suitable aldehydes and amines. The formation of azomethine $\mathbf{6}$ was very sluggish and was hastened by the addition of a small amount of zinc chloride as already suggested by C. G. and M. Macarovici ${ }^{11}$ for the preparation of Schiff bases of sulfanilamide.

2,3-Disubstituted-1,3-thiazolidin-4-ones (8-14) were obtained by reacting the Schiff bases with $\alpha$-mercaptoacetic acid in boiling benzene and removing the formed water by means of a Dean-Stark trap. The yields of thiazolidinone derivatives were improved if aldehydes and amines were directly condensed in refluxing benzene solution, followed by addition of $\alpha$-mercaptoacetic acid and continuing the heating until reaction completion, avoiding the isolation of the Schiff bases (Scheme 1).

In all these reactions small amounts of acidic side products were isolated. In the condensations involving 4-fluoro- and 4-methylbenzaldehyde the side products were purified and found to correspond to the thioacetals 15 (a, $\mathrm{Z}=\mathrm{CF}, \mathrm{X}, \mathrm{Y}=\mathrm{CH} ; \mathbf{b}, \mathrm{Z}=\mathrm{CCH}_{3}, \mathrm{X}, \mathrm{Y}=\mathrm{CH}$ ).

Compound 15 a was also obtained by direct condensation of -mercaptoacetic acid and 4fluorobenzaldehyde, whichever was the ratio between the reactants. 

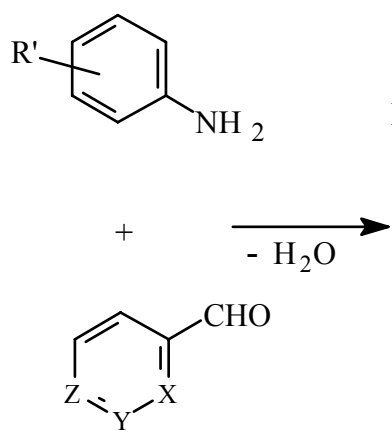

$\mathrm{X}=\mathrm{N} ; \mathrm{Y}, \mathrm{Z}=\mathrm{CH}$

$\mathrm{Z}=\mathrm{CF} ; \mathrm{X}, \mathrm{Y}=\mathrm{CH}$ $\mathrm{R}^{\prime}=3-\mathrm{CF}_{3} ; 4-\mathrm{SO}_{2} \mathrm{NH}_{2} ; 4-\mathrm{SO}_{2} \mathrm{CH}_{3}$<smiles>[R]c1ccc(NC=O)cc1</smiles>

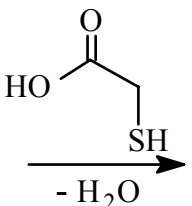

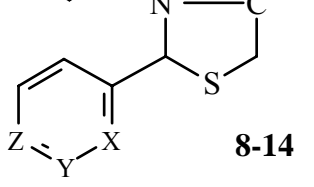<smiles>O=C(O)CSC(SCC(=O)O)c1ccc[Y]n1</smiles>

15

\section{Scheme 1}

The Schiff bases 4-7 and the thiazolidinone derivatives 8-14 were screened for antiinflammatory activity; compounds which were active in this test were assayed also for antinociceptive activity. Moreover, representative compounds (8-10) were tested for inhibition of arachidonic acid induced platelet aggregation, which implicates inhibition of cycloxygenase-1. A preliminary account of this work was communicated in $2001 .^{12}$

The results of the antiinflammatory and antinociceptive assays are summarized in Table 1.

Nine out of the eleven test compounds exhibited significant inhibition of the carrageenaninduced rat paw edema at the oral dose of $200 \mathrm{mg} / \mathrm{kg}$ and four of them were active also at $100 \mathrm{mg} / \mathrm{kg}$. Lower dose were ineffective; however compound 8, which at the doses of 200 and $100 \mathrm{mg} / \mathrm{kg}$ produced some mortality, was significantly active at $50 \mathrm{mg} / \mathrm{kg}$.

Both kinds of compounds (Schiff bases and thiazolidinone derivatives) displayed good level of activity, which resulted mainly related to the nature of substituents on the aromatic rings, with the methylsulfonyl group producing a higher edema inhibition than the amidosulfonyl one.

Indeed, the most active compounds were the azomethine $\mathbf{6}$ and the thiazolidinone 13, producing respectively, at the dose of $200 \mathrm{mg} / \mathrm{kg}$ p.o., $67 \%$ and $78 \%$ edema inhibition, while celecoxib at the same dosage produced $45 \%$ inhibition. ${ }^{13}$

The antiinflammatory action seems to be long lasting, as it was observed for compounds 6 and 13, whose anti-edema activity decreased only slightly between the second and the fourth hour after the carrageenan injection.

On the whole, considering also the azomethines 1-3 previously described, ${ }^{1}$ it may be observed that the building up of the heterocyclic ring on the azomethine group produces only minor (improving or detrimental) effects on the anti-edema activity. 
Table 1. Antinflammatory and antinociceptive activities of compounds 4-14

\begin{tabular}{|c|c|c|c|}
\hline Compound & $\begin{array}{l}\text { Tested dose } \\
\text { (mg/kg; p.o.) }\end{array}$ & $\begin{array}{c}\text { Antiinflammatory activity in } \\
\text { rat }^{\mathrm{a}} \\
(\% \text { edema inhibition })\end{array}$ & $\begin{array}{l}\text { Antinociceptive activity in } \\
\text { mice }^{\mathrm{b}} \\
\text { (\% reduction of writhings })\end{array}$ \\
\hline \multirow[t]{2}{*}{4} & 200 & $26 * *$ & $\mathrm{nt}$ \\
\hline & 100 & 14 & $\mathrm{nt}$ \\
\hline \multirow[t]{2}{*}{5} & 200 & $67^{\wedge}$ & 8 \\
\hline & 100 & 8 & $\mathrm{nt}$ \\
\hline \multirow[t]{3}{*}{6} & 200 & $68^{\wedge}$ & 9 \\
\hline & 100 & $59^{\wedge}$ & $\mathrm{nt}$ \\
\hline & 50 & 14 & $\mathrm{nt}$ \\
\hline \multirow[t]{3}{*}{7} & 200 & $51^{\wedge}$ & 12 \\
\hline & 100 & $44^{*}$ & $\mathrm{nt}$ \\
\hline & 50 & 26 & $\mathrm{nt}$ \\
\hline \multirow[t]{4}{*}{8} & 200 & $\S$ & $\mathrm{nt}$ \\
\hline & 100 & $\S$ & $\mathrm{nt}$ \\
\hline & 50 & $37 *$ & 0 \\
\hline & 25 & 9 & $\mathrm{nt}$ \\
\hline \multirow[t]{2}{*}{9} & 200 & $49^{\wedge}$ & $26 * *$ \\
\hline & 100 & 0 & $\mathrm{nt}$ \\
\hline \multirow[t]{3}{*}{10} & 200 & $40 *$ & $47^{\wedge}$ \\
\hline & 100 & 8 & $44^{*}$ \\
\hline & 50 & nt & 25 \\
\hline 11 & 200 & 25 & nt \\
\hline \multirow[t]{3}{*}{12} & 200 & $47^{\wedge}$ & 0 \\
\hline & 100 & $26^{* *}$ & $\mathrm{nt}$ \\
\hline & 50 & 14 & $\mathrm{nt}$ \\
\hline \multirow[t]{3}{*}{13} & 200 & $78^{\wedge}$ & $26 * *$ \\
\hline & 100 & 52 & $\mathrm{nt}$ \\
\hline & 50 & 0 & $\mathrm{nt}$ \\
\hline \multirow[t]{2}{*}{14} & 200 & $57^{\wedge}$ & $30 *$ \\
\hline & 100 & 26 & 22 \\
\hline indomethacin & 6 & $88^{\wedge}$ & $85^{\wedge}$ \\
\hline
\end{tabular}

${ }^{\text {a }}$ Carrageenan-induced paw edema test $(n=5)$; statistical significance versus control group ( $n=48$; control value $=201 \pm 61$ ) evaluated by t-test. ${ }^{b}$ Acetic acid-induced writhing test $(n=5)$; statistical significance versus control group $(n=21$; control value $=51 \pm 8)$ evaluated by the Mann-Whitney test. ${ }^{\wedge} \mathrm{P}<0.001 ;{ }^{*} \mathrm{P}<0.01 ; * * \mathrm{P}<0.05$ vs. control. $\S$ toxic dose. $\mathrm{nt}=$ not tested.

Though diarylazomethines can exist as cis/trans geometrical isomers, the trans conformation is the preferred one: thus Schiff bases and thiazolidinone derivatives should hit different binding 
sites. Nevertheless, one cannot exclude that in the biological medium Schiff bases assume a cis conformation somehow favoured by a progressive interaction with receptor's binding sites. Thus the observed activity of both types of tested compounds might be linked to a same scaffold well fitting into the cyclooxygenase cavity.

Moreover it is worthy to observe that the thiazolidinone derivatives possess a chiral carbon and thus their activity might be configuration dependant. Attempts to resolve the enantiomeric mixtures are in progress for the basic compounds 8-10.

The nine compounds exhibiting antiinflammatory activity were also assayed for antinociceptive action in the writhing test; only three of them displayed significant activity at the highest dose used (200 mg/kg, p.o.). The analgesic activity was generally weak and, moreover, did not correlate with the antiflogistic one; thus the structural requirements (and possibly the mechanisms) for the two activity seem to be quite different. This is not the case for "coxib" drugs, whose antiinflammatory and antinociceptive activities run parallely. Indeed, in the same experimental conditions presently used, Menozzi et al. ${ }^{16}$ observed that at the dose of $200 \mathrm{mg} / \mathrm{Kg}$ p.o. celecoxib produced a $45 \%$ edema inhibition and also a $77 \%$ reduction of the writhings number.

It is worth noting that in a collateral, ongoing research, aimed to discover novel structures endowed with platelet antiaggregating activity, it was observed that three thiazolidinone derivatives (8-10) at $30 \mu \mathrm{M}$ concentration failed to inhibit the rabbit platelet aggregation induced by $100 \mu \mathrm{M}$ arachidonic acid and, therefore, to inhibit the COX-1.

Indeed, the inhibition of arachidonic acid induced platelet aggregation provides an indirect proof of inhibition of COX-1, since the latter is the only enzyme isoform so far detected in platelets. ${ }^{14,15}$ Thus, even if we cannot exclude that at higher concentrations some antiaggregating and, hence, some COX-1 inhibiting activity could be displayed by our compounds, the presently negative results support the possibility that the observed strong antiedema activity of the relevant compounds could be due to selective inhibition of COX-2.

In conclusion, the previously observed strong antiinflammatory activity of Schiff bases has been now confirmed in a set of new compounds. The building up of a thiazolidinone ring on the azomethine group, while generating close structural analogues of coxib type of NSAIDs, had only minor effects (either improving or detrimental) on the anti-edema activity of the starting Schiff base. Thus the latter activity might be considered as linked mainly to the diarylazomethine backbone in the cis conformation, with only secondary contributions from either the azomethine double bond or the thiazolidinone ring. However this issue deserves further investigation.

The lack of platelet anti-aggregating activity, observed for a few of the relevant thiazolidinone derivatives, suggests that the anti-edema action is not linked to inhibition of COX-1 and might be due to selective COX-2 inhibition.

Thus further investigations are warranted in order to check such an interesting possibility or, in any case, to find the origin of the antiinflammatory activity of Schiff bases and thiazolidinone derivatives. 


\section{Experimental Section}

General Procedures. Melting points were determined by the capillary method on a Büchi apparatus and are uncorrected. Elemental analyses were performed with CE EA $1110 \mathrm{CHNS}-\mathrm{O}$ instrument; for the trifluoromethylderivatives 8, 9, 10 the $\mathrm{H}$ content was unreliable. UV and IR spectra were recorded respectively on Perkin Elmer model 550S and Paragon 1000 PC spectrophotometers; ${ }^{1} \mathrm{H}-\mathrm{NMR}$ were taken on a Varian Gemini 200 spectrometer, using $\mathrm{CDCl}_{3}$ or DMSO- $\mathrm{d}_{6}$ as solvent with TMS as internal standard.

\section{General method for the preparation of azomethines 4-7}

To a solution of 5-10 mmol of 4-aminobenzensulfonamide or 4-methylsulfonylaniline (prepared as described ${ }^{16}$ ) in 40-50 $\mathrm{ml}$ of absolute ethanol, 6-12 mmol of 4-methyl- or 4-fluorobenzaldehyde were added and the mixture was refluxed for a variable time: $6 \mathrm{~h}$ for compound 5, 24-30 $\mathrm{h}$ for the remaining. In the case of compound $\mathbf{6}$, a small amount of zinc chloride was added.

After cooling the precipitate was collected, the solution was concentrated and a second crop of crystals was obtained. The joined fractions were washed with dry ether or acetone to remove some unreacted aldehyde and then crystallized from absolute ethanol; compound 5 was crystallized by dissolution in DMF and gradual addition of absolute ethanol.

4. m.p. $151-152^{\circ} \mathrm{C}$. Yield 78\%. Anal. Calcd. for $\mathrm{C}_{13} \mathrm{H}_{11} \mathrm{FN}_{2} \mathrm{O}_{2} \mathrm{~S}$ : C, 56.11; H, 3.98; N, 10.07; S, 11.52. Found: C, 55.94; H, 3.96; N, 9.90; S, 10.85. UV (ethanol) $\lambda_{\max }(\mathrm{nm}): 223 \mathrm{sh}, 230 \mathrm{sh}, 265$, 304sh. ${ }^{1} \mathrm{H}$ NMR (DMSO-d 6 ) $\delta$ ppm: 7.3-7.4 (m, 4H arom. $+2 \mathrm{H} \mathrm{SO}_{2} \mathrm{NH}_{2}$, collapsing with $\mathrm{D}_{2} \mathrm{O}$ ); 7.8-8.1 (2 m, 2H+2H arom.); $8.68(\mathrm{~s}, 1 \mathrm{H},-\mathrm{CH}=\mathrm{N}-)$.

5. m.p. $193-195^{\circ} \mathrm{C}$. Yield $49 \%$. Anal. Calcd. for $\mathrm{C}_{14} \mathrm{H}_{14} \mathrm{~N}_{2} \mathrm{O}_{2} \mathrm{~S}$ : C, 61.29; H, 5.14; N,10.21; S, 11.69. Found: C, 61.52; H, 5.07; N, 10.31; S, 11.62. UV (ethanol) $\lambda_{\max }(\mathrm{nm}): 216,274,308 \mathrm{sh} .{ }^{1} \mathrm{H}$ NMR (DMSO-d $) \delta$ ppm: $2.41\left(\mathrm{~s}, 3 \mathrm{H}, \mathrm{CH}_{3}\right) ; 7.30-7.43\left(\mathrm{~m}, 4 \mathrm{H}\right.$ arom. $+2 \mathrm{H} \mathrm{SO}_{2} \mathrm{NH}_{2}$ collapsing with $\left.\mathrm{D}_{2} \mathrm{O}\right) ; 7.80-7.92$ (m, $4 \mathrm{H}$ arom.); 8.61 (s, $\left.1 \mathrm{H},-\mathrm{CH}=\mathrm{N}-\right)$.

6. m.p. $138.5-140^{\circ} \mathrm{C}$. Yield $43 \%$. Anal. Calcd. for $\mathrm{C}_{14} \mathrm{H}_{12} \mathrm{FNO}_{2} \mathrm{~S}$ : C, 60.64; H, 4.36; N, 5.05; S, 11.56. Found: C, 60.28; H, 4.25; N, 4.99; S, 11.19. UV (ethanol) $\lambda_{\max }(\mathrm{nm}): 220 \mathrm{sh}, 230 \mathrm{sh}, 268$, 307sh. ${ }^{1} \mathrm{H}$ NMR (DMSO-d $\left.{ }_{6}\right) \delta$ ppm: 3.24 (s, 3H, $\left.\mathrm{SO}_{2} \mathrm{CH}_{3}\right) ; 7.30-8.15$ (2m, 4H+4H arom.); 8.66 (s, $1 \mathrm{H},-\mathrm{CH}=\mathrm{N}-)$.

7. m.p. $172-175^{\circ}$ C. Yield 51\%. Anal. Calcd. for $\mathrm{C}_{15} \mathrm{H}_{15} \mathrm{NO}_{2} \mathrm{~S}$ : C, 65.91; H, 5.53; N, 5.12; S, 11.73. Found: C, 66.27; H, 5.68; N, 5.18; S, 11.30. UV (ethanol) $\lambda_{\max }(\mathrm{nm}): 212 \mathrm{sh}, 229 \mathrm{sh}, 276$, 308sh. ${ }^{1} \mathrm{H}$ NMR (DMSO-d 6 ) $\delta$ ppm: $2.40\left(\mathrm{~s}, 3 \mathrm{H}, \mathrm{CH}_{3}\right) ; 3.24\left(\mathrm{~s}, 3 \mathrm{H}, \mathrm{SO}_{2} \mathrm{CH}_{3}\right) ; 7.30-8.00(2 \mathrm{~m}$, $4 \mathrm{H}+4 \mathrm{H}$ arom.); 8.60 (s, $1 \mathrm{H},-\mathrm{CH}=\mathrm{N}-)$.

\section{General method for the preparation of 2,3-disubstituted 1,3-thiazolidin-4-ones 8-14}

A solution (or suspension) of the suitable aldehyde and aminocompound (10 mmol each) in dry benzene $(50 \mathrm{ml})$ was heated under reflux in a flask connected to a Dean-Stark trap for 1 to $18 \mathrm{~h}$ until the formation of the azomethine did not increase further. 
A solution of $\alpha$-mercaptoacetic acid $(20 \mathrm{mmol})$ in benzene was added and the mixture was refluxed for additional 7 to $30 \mathrm{~h}$.

The completion of the condensation was followed through TLC $\left(\mathrm{SiO}_{2}\right.$, eluting with $\mathrm{CH}_{2} \mathrm{Cl}_{2}+2 \%$ $\mathrm{MeOH})$ and the volume of water collected in the Dean-Stark trap.

Benzene was removed under reduced pressure and the residue was dissolved in dichloromethane and shaken with $5 \% \mathrm{Na}_{2} \mathrm{CO}_{3}$ solution and then with water. The solvent was removed and the residue was either distilled in vacuo (0.05 torr) or chromatographed on silica gel, eluting firstly with dichloromethane and successively with $\mathrm{CH}_{2} \mathrm{Cl}_{2}$ and increasing amount of methanol.

8. m.p. $75-77^{\circ} \mathrm{C}$ (ethanol/dry ether). Yield 55\%. Anal. Calcd. for $\mathrm{C}_{15} \mathrm{H}_{11} \mathrm{~F}_{3} \mathrm{~N}_{2} \mathrm{OS}$ : C, 55.55; $\mathrm{H}$, 3.42; N, 8.64; S, 9.89. Found: C, 55.26; H, nd; N, 8.52; S, 9.30. UV (ethanol) $\lambda_{\max }(\mathrm{nm}): 244$, 270sh. ${ }^{1} \mathrm{H}$ NMR $\left(\mathrm{CDCl}_{3}\right) \delta$ ppm: $3.80(\mathrm{~d}, 1 \mathrm{H}, \mathrm{J}=15.7 \mathrm{~Hz}, \mathrm{H}-5$ thiazolidinone); 4.10 (dd, 1H, J = 15.7 and $1.3 \mathrm{~Hz}, \mathrm{H}-5$ thiazolidinone); 6.13 (d, 1H, J =1.3 Hz, H-2 thiazolidinone); 7.15-7.80 (m, $7 \mathrm{H}$ arom.); 8.50-8.65 (m, $1 \mathrm{H}$ arom).

9. m.p. $95.5-97^{\circ} \mathrm{C}$ (ethanol/dry ether). Yield $46 \%$. Anal. Calcd. for $\mathrm{C}_{15} \mathrm{H}_{11} \mathrm{~F}_{3} \mathrm{~N}_{2} \mathrm{OS}$ : C, 55.55; $\mathrm{H}$, 3.42; N, 8.64; S, 9.89. Found: C, 55.48; H, nd; N, 8.68; S, 9.55. UV (ethanol) $\lambda_{\max }(\mathrm{nm}$ ): 240 , 261sh, 269sh. ${ }^{1} \mathrm{H}$ NMR (DMSO-d 6 ) $\delta$ ppm: 3.97 (d, 1H, J=14.4 Hz, H-5 thiazolidinone); 4.13 (dd, $1 \mathrm{H}, \mathrm{J}=17$ and $1.4 \mathrm{~Hz}, \mathrm{H}-5$ thiazolidinone); 6.73 (s, 1H, H-2 thiazolidinone); 7.3-8.0 (m, $6 \mathrm{H}$ arom.); 8.4-8.7 (m, 2H arom.).

10. m.p. $106-107.5^{\circ} \mathrm{C}$ (dry ether). Yield $46 \%$. Anal. Calcd. for $\mathrm{C}_{15} \mathrm{H}_{11} \mathrm{~F}_{3} \mathrm{~N}_{2} \mathrm{OS}$ : C, 55.55; $\mathrm{H}$, 3.42; N, 8.64; S, 9.89. Found: C, 55.80; H, nd; N, 8.57; S, 9.62. UV (ethanol) $\lambda_{\max }$ (nm): 236 , 260sh, 270sh. ${ }^{1} \mathrm{H}$ NMR $\left(\mathrm{CDCl}_{3}\right) \delta$ ppm: 3.87 (dd, $1 \mathrm{H}, \mathrm{J}=16$ and $0.6 \mathrm{~Hz}, \mathrm{H}-5$ thiazolidinone); 4.01 (dd, $1 \mathrm{H}, \mathrm{J}=16$ and $1.3 \mathrm{~Hz}, \mathrm{H}-5$ thiazolidinone); 6.1 (s, 1H, H-2 thiazolidinone); 7.15-7.25 (m, 2H arom.); 7.30-7.55 (m, 4H arom.); 8.50-8.70 (m, 2H arom).

11. m.p. $160-161^{\circ} \mathrm{C}\left(\mathrm{CHCl}_{3}\right)$. Yield 10.3\%. Anal. Calcd. for $\mathrm{C}_{15} \mathrm{H}_{13} \mathrm{FN}_{2} \mathrm{O}_{3} \mathrm{~S}_{2}+0.5 \mathrm{H}_{2} \mathrm{O}$ : C, 49.85; H, 3.90; N, 7.75; S, 17.74. Found: C, 50.15; H, 3.79; N, 7.68; S, 16.94. UV (ethanol) $\lambda_{\max }$ (nm): 252. ${ }^{1} \mathrm{H}$ NMR (DMSO-d 6 ) $\delta$ ppm: 3.94 (d, 1H, J=15.8 Hz, H-5 thiazolidinone); 4.08 (d, $1 \mathrm{H}, \mathrm{J}=15.8 \mathrm{~Hz}, \mathrm{H}-5$ thiazolidinone); 6.66 (s, 1H, H-2 thiazolidinone); 7.05-7.20 (m, 2H arom.); 7.33 (s, 2H, $\mathrm{SO}_{2} \mathrm{NH}_{2}$ collapsing with $\mathrm{D}_{2} \mathrm{O}$ ); 7.45-7.60 (m, 4H arom.); 7.70-7.80 (m, $2 \mathrm{H}$ arom.).

12. m.p. $197-198^{\circ} \mathrm{C}$ (ethanol). Yield $15,2 \%$. Anal. Calcd. for $\mathrm{C}_{16} \mathrm{H}_{16} \mathrm{~N}_{2} \mathrm{O}_{3} \mathrm{~S}_{2}$ : C, 55.15; H, 4.63; N, 8.04; S, 18.40. Found: C, 55.12; H, 4.70; N, 7.92; S, 18.16. UV (ethanol) $\lambda_{\max }(\mathrm{nm}): 225 \mathrm{sh}$, 251. ${ }^{1} \mathrm{H}$ NMR $\left(\mathrm{DMSO}_{6}\right) \delta$ ppm: $2.23\left(\mathrm{~s}, 3 \mathrm{H}, \mathrm{CH}_{3}\right) ; 3.93(\mathrm{~d}, 1 \mathrm{H}, \mathrm{J}=14.6 \mathrm{~Hz}, \mathrm{H}-5$ thiazolidinone); 4.06 (d, 1H, J=14.6 Hz, H-5 thiazolidinone); 6.61 (s, 1H, H-2 thiazolidinone); 7.05-7.30 (m, $2 \mathrm{H}+2 \mathrm{H}$ arom., p-substitution); $7.32\left(\mathrm{~s}, 2 \mathrm{H}, \mathrm{SO}_{2} \mathrm{NH}_{2}\right.$ collapsing with $\left.\mathrm{D}_{2} \mathrm{O}\right)$; 7.507.80 (m, 2H+2H arom., p-substitution).

13. m.p. $221-223^{\circ} \mathrm{C}$ (dry ether). Yield $44 \%$. Anal. Calcd. for $\mathrm{C}_{16} \mathrm{H}_{14} \mathrm{FNO}_{3} \mathrm{~S}_{2}$ : C, 54.69; H, 4.02; N, 3.99; S, 18.25. Found: C, 54.37; H, 4.20; N, 3.79; S, 18.41. UV (ethanol) $\lambda_{\max }(\mathrm{nm}): 256 .{ }^{1} \mathrm{H}$ NMR (DMSO-d $)_{6} \delta$ ppm: $3.19\left(\mathrm{~s}, 3 \mathrm{H}, \mathrm{SO}_{2} \mathrm{CH}_{3}\right) ; 3.94\left(\mathrm{~d}, 1 \mathrm{H}, \mathrm{J}_{\mathrm{gem}}=15.56 \mathrm{~Hz}, \mathrm{H}-5\right.$ thiazolidinone); $4.09\left(\mathrm{~d}, 1 \mathrm{H}, \mathrm{J}_{\mathrm{gem}}=15.56 \mathrm{~Hz}, \mathrm{H}-5\right.$ thiazolidinone $) ; 6.71 \quad(\mathrm{~s}, 1 \mathrm{H}, \mathrm{H}-2$ thiazolidinone); 7.05-7.55 (m, 2H+2H arom., p-substitution); 7.55-8.00 (m, 2H+2H arom., psubstitution). 
14. m.p. 206-207 ${ }^{\circ} \mathrm{C}$ (acetone). Yield $36 \%$. Anal. Calcd. for $\mathrm{C}_{17} \mathrm{H}_{17} \mathrm{NO}_{3} \mathrm{~S}_{2}$ : C, 58.77; $\mathrm{H}, 4.93$; $\mathrm{N}$, 4.03; S, 18.45. Found: C, 58.83; H, 5.23; N, 4.07; S, 17.95. UV (ethanol) $\lambda_{\max }$ (nm): $222 \mathrm{sh}, 258$. ${ }^{1} \mathrm{H}$ NMR $\left(\mathrm{DMSO}_{6}\right) \delta$ ppm: $2.22\left(\mathrm{~s}, 3 \mathrm{H}, \mathrm{CH}_{3}\right) ; 3.19\left(\mathrm{~s}, 3 \mathrm{H}, \mathrm{SO}_{2} \mathrm{CH}_{3}\right) ; 3.93(\mathrm{~d}, 1 \mathrm{H}, \mathrm{J}=14.4 \mathrm{~Hz}$, $\mathrm{H}-5$ thiazolidinone); 4.07 (dd, $1 \mathrm{H}, \mathrm{J}=17.6$ and 0.76, H-5 thiazolidinone); $6.66(\mathrm{~s}, 1 \mathrm{H}, \mathrm{H}-2$ thiazolidinone); 7.00-7.40 (m, $2 \mathrm{H}+2 \mathrm{H}$ arom., p-substitution); 7.55-7.95 (m, $2 \mathrm{H}+2 \mathrm{H}$ arom., psubstitution).

\section{4-Substituted-benzylidene-dimercapto-diacetic acids 15 a, b}

In the cases of the preparations of thiazolidinones 13 and 14, the alkaline solution used to remove the acidic compounds from the reaction mixture was acidified and extracted with ether. The solvent was evaporated and the semisolid residue was pressed on a porous porcelain plate to remove the oil. The solid residue was crystallized from dichloromethane.

15a. m.p. $156-158^{\circ} \mathrm{C}$. Yield $49 \%$. Anal. Calcd. for $\mathrm{C}_{11} \mathrm{H}_{11} \mathrm{FO}_{4} \mathrm{~S}_{2}$ : C, 45.51; H, 3.82; S, 22.09 . Found: C, 45.68; H, 3.89; S, 22.14. IR (KBr) $\left(\mathrm{cm}^{-1}\right)$ : 3161-2932 broad, 1734, 1668, 1598, 1506, 1220, 1152. ${ }^{1} \mathrm{H}$ NMR (DMSO-d 6 ) $\delta$ ppm: 3.24 (d, 2H, J=15.4 Hz, $\left.\underline{\mathrm{CH}}_{2} \mathrm{COOH}\right) ; 3.41(\mathrm{~d}, 2 \mathrm{H}$, $\left.\mathrm{J}=15.4 \mathrm{~Hz}, \underline{\mathrm{SCH}}_{2} \mathrm{COOH}\right) ; 5.31(\mathrm{~s}, 1 \mathrm{H}, \mathrm{CH}) ; 7.1-7.5$ (m, 2H+2H p-substitution); 12.7 (s broad, $2 \mathrm{H}, 2 \mathrm{COOH}$ collapsing with $\left.\mathrm{D}_{2} \mathrm{O}\right)$

15b. m.p. $125-128^{\circ} \mathrm{C} .{ }^{1} \mathrm{H}$ NMR (DMSO-d 6 ) $\delta$ ppm: 2.30 (s, 3H, $\mathrm{CH}_{3}$ ); 3.19 (d, 2H, J=15.4 Hz, $\left.\underline{\mathrm{SCH}}_{2} \mathrm{COOH}\right) ; 3.38\left(\mathrm{~d}, \mathrm{~J}=15.4 \mathrm{~Hz}, 2 \mathrm{H}, \underline{\mathrm{SCH}}_{2} \mathrm{COOH}\right) ; 5.25(\mathrm{~s}, 1 \mathrm{H}, \mathrm{CH}) ; 7.00-7.40(\mathrm{~m}, 2 \mathrm{H}+2 \mathrm{H}$, p-substitution); 12.7 (s broad, $2 \mathrm{H}, 2 \mathrm{COOH}$ collapsing with $\mathrm{D}_{2} \mathrm{O}$ ).

The 4-fluorobenzylidene dimercaptodiacetic acid 15a, was also obtained by heating at reflux for $15 \mathrm{~h}$ the solution of 4-fluorobenzaldehyde $(3 \mathrm{mmol})$ and $\alpha$-mercaptoacetic acid $(6 \mathrm{mmol})$ in 15 $\mathrm{ml}$ of dry toluene. After removing the solvent, the residue was rinsed with dichloromethane leaving white crystals (48\% yield) that were crystallized as above. Mixed m.p. was unchanged.

Pharmacology. For in vivo assays male albino Sprague-Dawley rats (120-150 g) and male Swiss mice (15-25 g) were used. Animals were fasted for $15 \mathrm{~h}$ before treatment, but had always free access to water. All compounds were administered orally by a gastric tube, as finely homogenized suspension in $0.5 \%$ carboxymethylcellulose (CMC) ( $1 \mathrm{ml} / 100 \mathrm{~g}$ body weight), at the initial dose of $200 \mathrm{mg} / \mathrm{kg}$.

Compounds which exhibited a statistically significant activity at this dose were further tested at doses decreasing by a factor of 2 , always in the same volume of $0.5 \% \mathrm{CMC}$. Controls received the same volume of CMC dispersion.

For in vitro assays, the dissolution of test compounds in a buffer was speeded up by means of DMSO; the final concentration of DMSO not interfering with test was $0.1 \%$.

Antiinflammatory activity. The carrageenan-induced paw edema test $^{17}$ was performed in groups of five rats. Sixty minutes after administering the test compound, $0.1 \mathrm{ml}$ of $1 \%$ carrageenan suspension in saline was injected into the plantar surface of the right hind paw of each rat. Paw volume, as determined by measuring the volume of water displaced after 
immersing paw up to the lateral malleous level, was recorded immediately after the carrageenan injection and again $2 \mathrm{~h}$ later. The difference between these two volumes was taken as edema volume. For the most active compounds the edema volume was measured also after $4 \mathrm{~h}$. The percent inhibition of the edema of treated rats with respect to control animals was calculated and compared with that produced by indomethacin $(6 \mathrm{mg} / \mathrm{kg}$, p.o.), used as reference drug. Statistical significance versus control group was evaluated by the Student's t-test.

Analgesic activity. The writhing test ${ }^{18}$ was performed in groups of five mice. One hour after the administration of the test compound, $0.01 \mathrm{ml} / \mathrm{g}$ of $0.6 \%$ acetic acid solution was injected intraperitoneally in each mouse. The writhing movements of each animal were counted for 15 min (between the fifth and 20th min after the injection of the irritant). The antinociceptive effect was expressed as the percent reduction of writhing number compared with the control group. Indomethacin $(6 \mathrm{mg} / \mathrm{kg}$, p.o.) was used as reference drug. Statistical significance versus control group was evaluated by the Mann-Whitney test.

Platelet aggregation inhibition. Blood from New Zealand rabbit $(2.75 \pm 0.25 \mathrm{~kg}$ body weight $)$ was collected in $0.13 \mathrm{M}$ trisodium citrate solution and centrifuged to obtain platelets rich plasma (PRP). A first sample of PRP was incubated at $37^{\circ} \mathrm{C}$ for $5 \mathrm{~min}$ before the addition of arachidonic acid (final conc. $100 \mu \mathrm{M}$ ). A second sample of PRP was incubated in the same conditions in the presence of test compound $(30 \mu \mathrm{M})$. Platelet aggregation was induced adding the agonist and after 5 min the maximal light transmission, obtained with and without the addition of the test compound, were compared and the percentage of inhibition of platelet aggregation was calculated. Inhibition by more than $50 \%$ indicated highly significant activity. Indomethacin at $0.3 \mu \mathrm{M}$ conc. gave $100 \%$ inhibition of platelet aggregation.

\section{Acknowledgments}

The financial support of the Italian Ministry of Education, University and Research (MIUR) is gratefully acknowledged.

\section{References}

1. Sparatore, F.; Pirisino, G.; Alamanni, M. C.; Manca-Dimich, P.; Satta, M. Boll. Chim. Farm. 1978, 117, 638; Chem. Abstr. 1979, 91, 13760 b.

2. Pala, G.; Donetti, A.; Mantegani, A.; Coppi, G.; Marazzi-Uberti, E.; Lumachi, B. Chim. Therap. 1971, 6, 10.

3. Dewhirst, F. E. Prostaglandins 1980, 20, 209.

4. Hadjipavlou-Litina, D. J.; Geronikaki, A. A. Drug Des. Discov. 1998, 15, 199.

5. Geronikaki, A.; Hadjipavlou-Litina, D.; Amourgianou, M. Farmaco 2003, 58, 489. 
6. Cardile, V.; Panico, A. M.; Geronikaki, A.; Gentile, B.; Ronsisvalle, G. Farmaco 2002, 57, 1009.

7. Harada, K. In The Chemistry of the carbon-nitrogen double bond, Patai, S. Ed., Interscience Publishers: London, New York, 1970; pp 255-298.

8. Talley, J. J. Progr. Med. Chem. 1999, 36, 201.

9. Dannhardt, G.; Kiefer, W. Eur. J. Med. Chem 2001, 36, 109.

10. Chavatte, P.; Yous, S.; Marot, C.; Baurin, N.; Lesieur, D. J. Med. Chem 2001, 44, 3223.

11. Macarovici, C. G.; Macarovici, M. Rev. Chim. Acad. Rep. Populair Roumaine 1956, 1, 91; Chem. Abstr. 1958, 52, 1996d.

12. Vazzana, I.; Sparatore, F. Hungarian-German-Italian-Polish Joint Meeting on Medicinal Chemistry, Budapest, 2001, Sept. 2-6, Book of Abstracts p 180.

13. Menozzi, G.; Merello, L.; Fossa, P.; Mosti, L.; Piana, A.; Mattioli, F. Farmaco 2003, 58, 795.

14. Vane, J. R.; Bakhle, Y. S.; Botting, R. M. Ann. Rev. Pharmacol. Toxicol. 1998, 38, 97.

15. Crofford L. J. J. Rheumatol. 1997, 24, suppl. 49 ,15.

16. Fuller, A. T.; Tonkin, I. M.; Walker, J. J. Chem. Soc. 1945, 633.

17. Winter, C. A.; Risley, E. A.; Nuss, G. W. Proc. Soc. Exp. Biol. Med. 1962, 111, 544.

18. Koster, R.; Anderson, M.; De Beer, E. J. Fed. Proc. 1959, 18, 412. 